\title{
USE OF VIRTUAL QUESTIONNAIRE AND DISSEMINATION AS A DATA COLLECTION STRATEGY IN SCIENTIFIC STUDIES
}

\author{
Fabiana Faleiros ${ }^{1}$, Christoph Käppler², Fernando Augusto Ramos Pontes ${ }^{3}$, Simone Souza da Costa Silva , \\ Fernanda dos Santos Nogueira de Goes ${ }^{5}$, Cibele Dias Cucick ${ }^{6}$
}

${ }^{1}$ Ph.D. in Rehabilitation Sciences. Professor, Departamento de Enfermagem Geral e Especializada, Escola de Enfermagem de Ribeirão Preto (EERP), Universidade de São Paulo (USP). Ribeirão Preto, São Paulo, Brazil. E-mail: fabifaleiros@eerp.usp.br

${ }^{2}$ Ph.D. in Psychology. Professor, Fakultät Rehabilitationswissenschaften, Universität Dortmund. Dortmund, Germany. E-mail: christoph. kaeppler@tu-dortmund.de

${ }^{3}$ Ph.D. in Psychology. Professor, Núcleo de Teoria e Pesquisa do Comportamento (NTPC) and Programa de Pós-graduação em Teoria e Pesquisa do Comportamento (PPGTPC), Universidade Federal do Pará (UFPA). Belém, Pará, Brazil. E-mail: farp1304@gmail.com

${ }^{4}$ Ph.D. in Psychology. Professor, NTPC and PPGTC/UFPA. Belém, Pará, Brazil. E-mail:symon.ufpa@gmail.com

${ }^{5}$ Ph.D. in Nursing. Professor, Departamento de Enfermagem Geral e Especializada, EERP/USP. Ribeirão Preto, São Paulo, Brazil. E-mail: fersngoes@eerp.usp.br

${ }^{6}$ Master's student, Graduate Program in Fundamental Nursing, EERP/USP. Ribeirão Preto, São Paulo, Brazil. E-mail: cicucick@ gmail.com

\begin{abstract}
This study describes the use of online questionnaires and their virtual dissemination as a data collection strategy in Germany. The online questionnaire was elaborated using a virtual platform, creating a link that was disseminated in virtual environments. Participants were 100 Germans with Spina Bifida; 149 people visited the link, 83 of them coming from virtual forums, 27 from emails, 26 from social networks, ten from the German association of spina bifida site and three from the university website. With $55.7 \%$ of the participants, the virtual forum was the most agile dissemination medium to capture the data. This data collection mode should be used in future research, involving different countries, due to the speed, saving, good use of answers and help to overcome the language barrier. Public policies that support people's access to the Internet are necessary, so that these studies can be conducted successfully.

DESCRIPTORS: Internet. Data collection. Research. Questionnaires. Spinal dysraphism.

\section{USO DE QUESTIONÁRIO ONLINE E DIVULGAÇÃO VIRTUAL COMO ESTRATÉGIA DE COLETA DE DADOS EM ESTUDOS CIENTÍFICOS}

\begin{abstract}
RESUMO: Este estudo teve como objetivo descrever o uso de questionário online e sua divulgação virtual como estratégia de coleta de dados na Alemanha. O questionário online foi elaborado com uma plataforma virtual, criando um link que foi divulgado em ambientes virtuais. Participaram 100 indivíduos alemães com Espinha Bífida; 149 pessoas visitaram o link, dessas 83 oriundas de fóruns virtuais, 27 e-mails, 26 redes sociais, dez do site da associação da espinha bífida alemã e três do site da universidade. Com 55,7\% dos participantes, o meio de divulgação mais ágil para captação foi o fórum virtual. Sugere-se que esse modo de coleta de dados seja utilizado para pesquisas futuras, envolvendo diversos países, devido à rapidez, economia, bom aproveitamento de respostas e por permitir ultrapassar a barreira linguística. Políticas públicas que apoiem o acesso da população à internet são necessárias, para que esses estudos sejam realizados com êxito. DESCRITORES: Internet. Coleta de dados. Pesquisa. Questionários. Disrafismo espinal.
\end{abstract}

\section{USO DE CUESTIONARIO Y DIVULGACIÓN VIRTUALES COMO ESTRATEGIA PARA LA RECOGIDA DE DATOS DE ESTUDIOS CIENTÍFICOS}

RESUMEN: Este estudio describe el uso de un cuestionario online y su divulgación virtual como una estrategia de recolección de datos. El instrumento online fue desarrollado utilizando una plataforma virtual, creando un link que se publicó en ambientes virtuales. Participaron 100 alemanes con Espina Bífida. 149 personas tuvieron acceso al link, 83 oriundos de foros virtuales, 27 de correos electrónicos, 26 de redes sociales, 10 provenientes de la asociación alemana de espina bífida y 3 del website de la universidad. Con el 55,7\% de los participantes, el medio de divulgación más ágil para la captura fue el foro virtual. Se sugiere que este método sea utilizado para investigaciones futuras que involucren varios países, esto debido a la velocidad, la economía, el buen uso de respuestas y por permitir a superar la barrera del idioma. Se requieren políticas públicas que apoyen el acceso de las personas a Internet, para que estos estudios se realicen con éxito.

DESCRIPTORES: Internet. Recolección de datos. Investigación. Cuestionarios. Disrafia espinal. 


\section{INTRODUCTION}

The description of the methodological procedures the researchers adopt is a relevant theme, as it reveals knowledge production strategies based on scientific evidence, and permits reflections on the facilities and frailties of each methodological strategy used in different contexts and regions. Systematic data collection plays a fundamental role for the quality and the length of scientific study, turning it into a theme of interest for the researchers. ${ }^{1}$

The traditional approaches to collect information from the research participants, such as face-toface interviews, telephone and printed questionnaires, are not always able to generate rapid results with economically feasible costs. In addition, they do not follow the populations' technological and dynamic trend. ${ }^{2}$ One example are the participation rate in epidemiological studies, which gradually dropped over the last decades, with even clearer drops in recent years. ${ }^{3-4}$ The reasons suggested for the drop in the response rates include the general decrease in volunteering, higher demands for participation in research and the use of mobile phones. ${ }^{1,4}$

As a result of the growing internet access all over the world, studies that use the virtual environment are a current trend for the data collection and a preference of most research subjects. ${ }^{1,4-7}$ Although the youngest age groups maintain the highest internet use, the adherence of older people to this tool has increased in recent years. ${ }^{8}$

Thus, the use of the Internet as an auxiliary resource for information exchange and dissemination permits the improvement and agility of the research process. In addition, it allows the researcher rapid and precise contact with the study participants. ${ }^{9}$

In Germany, about $85 \%$ of the homes have Internet access. In Brazil, according to data from the Instituto Brasileiro de Opinião Pública e Estatística (IBOPE) Nielsen Online 2012, when considering all connection sites, including homes, work, schools and lan houses, the number of users in Brazil is $94.2 \%$, corresponding to somewhat less than $50 \%$ of the Brazilian population. ${ }^{10}$ In view of these data and in the attempt to increase the use of and access to the Internet, in line with countries like Germany, the goal of the National Broadband Plan (PNBL) is to provide $88 \%$ of the Brazilian population with low-cost and high-speed Internet access in the near future. ${ }^{11}$

This increasing Internet use in all age ranges has encouraged researchers to develop virtual questionnaires as an alternative method to obtain answers in scientific research. The virtual environment flexibly and dynamically provides for the establishment of networks of people who share ideas and common experiences. ${ }^{12}$ The use of virtual tools also permits the dispersion of the information and the disclosure of nursing research, turning into a resource to promote and develop the profession. ${ }^{13}$ In that sense, the objective in this study was to describe the use of the online questionnaire and its virtual dissemination as a data collection strategy in a study Brazilian and German researchers undertook in Germany.

\section{METHOD}

The study was undertaken at the School of Rehabilitation Sciences of Dortmund University Germany, as part of a Doctoral dissertation intended to collect data from Germans diagnosed with Spina Bifida (SB) for the sake of a comparative study between Brazil and Germany on intermittent bladder catheterization in SB patients. A virtual questionnaire was chosen to collect the data, mainly because it permits the participation of individuals from the entire German territory, besides allowing Brazilian researchers without complete fluency in the German language to develop the research without the language bias during an interview. The Association of SB and Hidrocephaly (ASBH) - German - promoted contact with the SB patients and their relatives, allowing the researchers to get to know the main virtual environments the candidate participants used.

Approval and authorization for the research project was obtained from the Post-Graduation Committee of the School of Rehabilitation Sciences at Dortmund University and the boards of the ASBH and the Sternchen Forum (virtual forum used by ASBH members). Before starting the data collection with the virtual questionnaire, a virtual Free and Informed Consent Form was included, consisting of one page with information on the research and the request for authorization to use the data.

The calculation of the sample was based on Freeman's formula $n=10(k+1)$, with an alpha of 0.05 and considering maximum variance $(\mathrm{p}=0.50=50 \%)$. Thus, the sample calculation showed that least 100 answers (n) were necessary for a proportion estimate within the interval of $+/-5$ percentage points.

The sample consisted of 100 participants diagnosed with SB and experienced in the use of intermittent bladder catheterization (IC). The SB patients, aged 18 years or older, and/or their relatives over 18 years of age and experienced in assisted 
IC (when the SB patient was younger than 18 years) answered the research.

\section{RESULTS}

\section{Elaboration of data collection tool}

The data collection tool was a virtual questionnaire consisting of 57 questions, mostly multiple choice and using a Likert scale, elaborated to assess the context of intermittent bladder catheterization in Brazil and Germany in SB patients, for the sake of a descriptive and comparative research underlying a doctoral dissertation at the Fakultät Rehabilitationswissenschaften, Universität Dortmund. This tool was previously developed in Brazil and went through the translation, adaptation and validation process for use in the German context. The previously validated questionnaire was transported to an online platform (Survey Monkey) to facilitate the access and participation of individuals from all regions of Germany. The full questionnaire used in Germany is available through the link: https:/ / de.surveymonkey.com/r/ TUDortmund-spinabifida-brasilien-deutschland.

The data were collected in Germany between 2011 and 2012. Two months were needed to receive 100 fully completed questionnaires.

\section{Dissemination of data collection tool}

The research was widely disseminated, with the help of $\mathrm{ASBH}$, in the virtual media the study population used most.

To disseminate the tool, links to the questionnaire were posted in different virtual environments, including: the Sternchen Forum for relatives and patients with SB, the websites of Dortmund University and the ASBH, besides SB communities on social networks (StudiVZ and Facebook) and e-mails.

\section{Obtaining the answers}

In total, 149 individuals visited the link to the questionnaire. These visits, 83 came from virtual forums (71 from the Sternchen Forum and 12 from other forums), 27 from social networks, 26 from direct mailing to personal e-mails, ten from the ASBH website and three from the website of Dortmund University (Figure 1). Most visits to the online questionnaire came from virtual forums, capturing about $55.7 \%$ of the visitors ( $\mathrm{p} \geq 0.005)$.

The response time could not be assessed, although the participants could interrupt the comple- tion of the questionnaire and proceed at another time. Only one questionnaire could be completed per IP (Internet Protocol) address, which is a number a computer or router receives when connecting to the Internet. This measure was taken to impede repeated questionnaires from the same participant. No missing answers were found, as the tool used to develop the online questionnaire did not allow the participant to move on without having provided all requested answers.

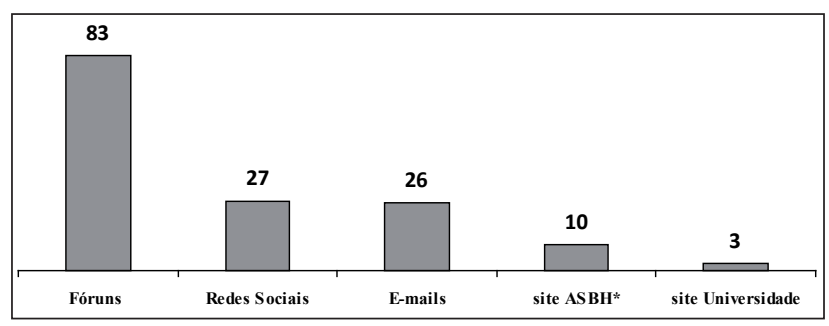

*ASBH (German Association of Spina Bifida and Hydrocephaly)

Figure 1 - Distribution of research dissemination sites according to number of visits received on virtual questionnaire link. Germany, 2011. (n=149)

The age of the German participants ranged between zero and 55 years, with an average age of 19.2 (SD \pm 13.7$)$, including children, young people and adults. Concerning who answered the virtual questionnaire, in $49.0 \%$ of the questionnaire, the SB patient answered, against $51 \%$ by 'another responsible caregiver', including 43 mothers, six fathers, one grandfather and one other responsible caregiver. As to gender, the sample consisted of 65 women and 35 men.

Out of 149 visitors to the virtual questionnaire link, only 100 fully answered the questionnaire and the virtual free and informed consent form, and were thus allowed to participate in the study. Thus, the utilization rate of the answers corresponded to $67 \%$.

The data collection took approximately 60 days and was interrupted when 100 fully answered questionnaires were reached, as defined by the sample calculation.

The costs to elaborate the data collection tool included the payment of the hosting rate and elaboration of the questionnaire on the online platform, calculated at about 24 USD per month.

\section{DISCUSSION}

The use of the virtual questionnaire made it possible to collect the data for this scientific study Brazilian researchers undertook in Germany. The 
most agile dissemination medium to capture the research participants was the virtual forum, representing $55.7 \%$ of all visitors to the questionnaire link. The time needed to collect the data was a positive factor, as it permitted the collection of 100 fully completed questionnaires in only two months.

This data collection possibility showed to be more effective than other attempts by other researchers, through printed questionnaires forwarded by conventional mail, in which the usage rate of the answers ranged between 12 to $25 \%$. As the usage rate of the answers to the virtual questionnaire corresponded to $67 \%$, better than the response usage rates of questionnaires posted via conventional mail in earlier studies. ${ }^{14-15}$

Studies seeking strategies to increase the answers to posted and virtual questionnaires have been developed earlier. ${ }^{12,15}$ These studies using posted questionnaires showed, however, that even after various attempts to increase the response rate, such as sending a stamped response letter and remuneration, this increase in the response rate is not significant, maintaining the data collection costly and lengthy. ${ }^{14}$ The convenience of answering the questionnaire virtually at home, without the work and time to prepare and forward the questionnaire by conventional mail, increases the response rate of virtual questionnaires. ${ }^{15}$

One aspect for discussion is the high cost of data collection through printed questionnaires. In an American study of 59,000 women, it was verified that the cost of developing and processing the postal questionnaire was four times higher than the virtual questionnaire, mainly due to the costs of forwarding and returning and the longer time to type and construct the database. ${ }^{16}$ In addition, the virtual questionnaires were filled out more completely than the printed questionnaires forwarded by conventional mail. Thus, the use of the virtual questionnaire resulted in cost savings and more complete answers. Nevertheless, a higher response rate was observed in younger participants and a lower rate in participants over 60 years of age. ${ }^{16}$ In this study, the costs to elaborate the virtual questionnaire were low (24 dollars/month).

In addition, through the use of the virtual questionnaire, an automated database could be obtained, directly transferred to SPSS or Excel, without typos in the transcription of the answers and more complete. As a resource was used to guide the participants through the completion, impeding the answering of the subsequent question before answering the current one for example, thus avoid- ing unanswered questions. This resources was also used and evidenced in other studies. ${ }^{17}$

Other studies comparing the two main data collection modes, a printed questionnaire and a virtual questionnaire, showed that there is no difference between them with regard to the collected results. ${ }^{6-7,18-19}$ Studies refer that the quality of the data collected based on online questionnaires can be higher, due to the higher response rate and the unnecessary double entry of the data..$^{17,20-21}$ Nevertheless, they alert to the possibility of privileging subjects with higher education levels in the constitution of the sample, creating a bias..$^{20,22}$

The relevance of the questionnaire elaboration phase should be considered to increase the response rate. ${ }^{15}$ Short, clear questionnaires have a greater chance of obtaining higher response rates. ${ }^{15,23}$ In this study, the elaboration phase of the tool was done carefully, first in Brazil, involving a multidisciplinary team with vast experience in the rehabilitation of individuals with SB, and later in Germany to undertake the adaptation and validation phase, also involving a German multidisciplinary team and the ASBH.

Various earlier studies exist in health, using a virtual questionnaire with the university or hospital audience (professors, students and health professionals), in which the researchers and participants know one another. This study showed yet another possibility that went further, from the territorial and international viewpoint, as the participation in the study was not restricted to individuals from a single region or institution. It allowed individuals from various parts of the country to participate in the study. In addition, this tool permitted the data collection by non-native researchers, as the primary researcher was not German, surpassing the language barrier and permitting international comparative studies. Using a translated, adapted and appropriately validated tool, data could be collecting in another country, with another language and culture, without the communication barrier impeding the study.

The advantages of using the virtual environment to collect data the researchers observed in the development of this research, in accordance with other experts, ${ }^{1,5-7,14-16}$ include: possibility to capture participants from different geographical locations at a low cost; impartiality and anonymity, not exposing the participants to the researcher's personal influence; participants' convenience, answering the tool at the moment they find most appropriate; researcher's facility to apply the tool to different 
participants; as the data are inserted electronically and transformed automatically into a database, the errors and spending on data typing are eliminated; visual and audio resources can be included to facilitate the completion of the tool, and the researchers can control the number of questionnaires completed real-time.

The researchers observed the following possible limitations of the online questionnaire: exclusion of digital illiterates, impeding help to the participant when (s)he does not understand a questionnaire, impossibility to know in what circumstances the questionnaire was answered. Nevertheless, solutions to the limitations of the virtual questionnaires will be increasingly studied and developed in the future, due to the benefits of this type of data collection. ${ }^{1}$

In that sense, reflecting on the need for multicenter and international studies, the virtual questionnaire and its dissemination through electronic media is an option for further study and improvement. New studies using electronic media for data collection should be stimulated, as the virtual environment is increasingly used to seek information on health themes. They are also a place for leisure, work, purchase and relationships that has become part of millions of people's daily life all over the world.

\section{CONCLUSION}

The use of virtual environments to develop health research represents an economic possibility, with a higher information and scientific production speed, which is capable of surpassing language barriers, permitting the development of international multicenter comparative studies. In addition, Internet research is more practical and convenient for the participants and can improve the number of answers obtained.

The study suggests that this data collection mode (virtual questionnaire and dissemination), when properly implemented, should be further developed and used in future research, mainly involving different countries, being a rapid and economical medium with a good response usage rate. Nevertheless, public policies that support the population's Internet access are needed to be able to successfully apply this type of method, using virtual media, in developing countries like Brazil.

\section{REFERENCES}

1. van Gelder MM, Bretveld RW, Roeleveld N. Webbased questionnaires: the future in epidemiology?
Am J Epidemiol. 2010 Dec 1; 172(11):1292-8.

2. Ekman A, Litton JE. New times, new needs; e-epidemiology. Eur J Epidemiol. 2007; 22(5):285-92.

3. Morton LM, Cahill J, Hartge P. Reporting participation in epidemiologic studies: a survey of practice. Am J Epidemiol. 2006 Feb 1; 163(3):197-203.

4. Galea S, Tracy M. Participation rates in epidemiologic studies. Ann Epidemiol. 2007 Sep; 17(9):643-53.

5. Akl EA, Maroun N, Klocke RA, Montori V, Schünemann HJ. Electronic mail was not better than postal mail for surveying residents and faculty. J Clin Epidemiol. 2005 Apr; 58(4):425-9.

6. Fleming CM, Bowden M. Web-based surveys as an alternative to traditional mail methods. J Environ Manage. 2009 Jan; 90(1):284-92.

7. Zuidgeest M,Hendriks M,Koopman L,Spreeuwenberg $\mathrm{P}$, Rademakers J. A comparison of a postal survey and mixed-mode survey using a questionnaire on patients' experiences with breast care. J Med Internet Res. 2011 Sep 27; 13(3):e68.

8. Project PIaAL. Pew Internet Project Data Memo. Washington, DC: Pew Research Center; 2009

9. Gil RF, Camelo SH, Laus AM. Nursing tasks in the Material Storage Center of hospital institutions. Texto Contexto Enferm [Internet]. 2013 [cited 2016 Jul 07]; 22(4):. Available from: http://www. scielo.br $/$ scielo.php?script $=$ sci_arttext\&pid $=$ S010407072013000400008\&lng=en\&nrm=iso\&tlng =en

10. IBOPE NO. Acesso à internet no Brasil atinge 94,2 milhões de pessoas. 2012 [cited 2013 Apr 16]. Available from: http://www.ibope.com.br/pt-br/noticias/ paginas/acesso-a-internet-no-brasil-atinge-94milhoes-de-pessoas.aspx

11. Santos RS. Plano Nacional poderá levar banda larga a $88 \%$ da população brasileira. Comitê Gestor da Internet no Brasil 2010: 53-57. [cited 2016 Feb 15]. Available from: http://www.cgi.br/publicacao/ plano-nacional-podera-levar-banda-larga-a-88-dapopulacao-brasileira

12. González MAS. Los modelos del razonamiento moral y la investigación de la ética utilizando internet: la "red de conciencia virtual", un proyecto de investigación inspirado en el coherentismo. Texto Contexto Enferm. 2005; 14(1):49-57.

13. Mendes IAC, Trevizan MA, Mazzo A, Godoy SD, Ventura CAA. Marketing profissional e visibilidade social na enfermagem: uma estratégia de valorização de recursos humanos. Texto Contexto Enferm. 2011; 20(4):788-95.

14. Carling C. International questionnaire postal response rate: an experiment comparing no return postage to provision of International Postage Vouchers"Coupon-Réponse International". BMC Health Serv Res. 2004; 4(1):16.

15. Edwards PJ, Roberts I, Clarke MJ, Diguiseppi C, Wentz R, Kwan I, et al. Methods to increase response 
to postal and electronic questionnaires. Cochrane Database Syst Rev. 2009 Jul 8;(3):MR000008.

16. Russell CW, Boggs DA, Palmer JR, Rosenberg L. Use of a web-based questionnaire in the Black Women's Health Study. Am J Epidemiol. 2010 Dec 1; 172(11):1286-91.

17. Smith MJ, Reiter MJ, Crist BD, Schultz LG, Choma TJ. Improving Patient Satisfaction Through ComputerBased Questionnaires. Orthopedics. 2016 Jan-Feb; 39(1):e31-5.

18. Deshpande AV, Sampang R, Smith GHH. Study of botulinum toxin $\mathrm{A}$ in neurogenic bladder due to spina bifida in children. ANZ J Surg. 2010; 80(4):250-3.

19. Callas PW, Solomon LJ, Hughes JR, Livingston AE. The influence of response mode on study results: offering cigarette smokers a choice of postal or online completion of a survey. J Med Internet Res. 2010 Oct 21; 12(4):e46.
20. Smith $A B$, King M, Butow P, Olver I. A comparison of data quality and practicality of online versus postal questionnaires in a sample of testicular cancer survivors. Psychooncology. 2013 Jan; 22(1):233-7

21. Kongsved SM, Basnov M, Holm-Christensen K, Hjollund NH. Response rate and completeness of questionnaires: a randomized study of Internet versus paper-and-pencil versions. J Med Internet Res. 2007 Sep 30; 9(3):e25

22. van den Berg MH, Overbeek A, van der Pal HJ, Versluys $A B$, Bresters D, van Leeuwen FE, et al. Using web -based and paper-based questionnaires for collecting data on fertility issues among female childhood cancer survivors: differences in response characteristics. J Med Internet Res. 2011 Sep 29; 13(3):e76.

23. Betz CL, Smith KA, Macias K, Bui K. Exploration of internet use: profile and preferences of transition-aged adolescents with spina bifida. Pediatr Nurs. 2014 JulAug; 40(4):173-8.
Correspondence: Fabiana Faleiros

Escola de Enfermagem de Ribeirão Preto da Universidade de

São Paulo

Departamento de Enfermagem Geral e Especializada

Avenida dos Bandeirantes, 3900

14040-902 - Monte Alegre, Ribeirão Preto, SP, Brasil

E-mail: fabifaleiros@eerp.usp 